\title{
Human Capital Risk and Talent Management Issues in the Insurance Market: Public Policy, Industry and Collegiate Education Perspectives*
}

\author{
W. Jean Kwon
}

The School of Risk Management, Insurance and Actuarial Science, St. John's University, New York, U.S.A. E-mail: KwonW@stjohns.edu

The human capital attraction and retention challenges in the insurance industry intensify due to a combining effect of demographic, social, economic and market-specific factors. In addition, there is human capital obsolescence risk. The study findings indicate that: the financial services occupation group requires high competency in cognitive abilities, social perspectives, management knowledge and communication skills, but not much in technical, physical/sensory or engineering skills; the insurance industry and most insurance companies have not attained a high reputation; and insurance is not a widely recognised profession by the public and many college students. Based on our macro- and micro-spective investigation of the industry and university education, we recommend: more public relations activities, closer work with local universities and their faculties for adoption of the field as a major; better talent recruitment, training and retention programmes; and preparedness for talent morbidity across financial services sectors and countries.

The Geneva Papers (2014) 39, 173-196. doi:10.1057/gpp.2013.11

Keywords: human capital; skills development; talent management; obsolescence risk; population ageing; collegiate education; RMI programme; globalisation

\section{Introduction}

The insurance industry has long been in the business of identifying and evaluating risks and architecting programmes to effectively control and finance the risks. By managing the risks of others, insurance companies help individuals - let alone giving them peace of mind against risk - better balance their current and future consumption of wealth. They assist entity-clients in managing operational, financial and strategic risks, thus helping them to be efficient and competitive. Risk financing via insurance and reinsurance is key business in this industry. The industry plays such an important role that no government would sustain economic development and growth without insurance service. Its importance rises as more countries become regionalised and globalised.

The insurance industry itself must preserve long-term financial and operational sustainability so as to fulfil its obligations to clients. More consumers need to be educated about insurance mechanisms and products. The government must also nurture themselves with knowledge about the industry and its players. Indeed, we are

\footnotetext{
* This paper has been granted the 2013 Shin Research Excellence Award - a partnership between The Geneva Association and the International Insurance Society-for its academic quality and relevance by decision of a panel of judges comprising both business and academic insurance specialists.
} 
witnessing significant improvements in these areas. Governments keep gaining a better understanding about the complex nature of insurance business, such as hybrid insurance products, mega-scale catastrophe risk securitisation, cross-border insurer operations and financial conglomeration. More and more governments are adopting higher regulatory/supervisory agency standards (e.g. IAIS Insurance Core Principles) and working jointly on important intergovernmental protocols (e.g. Common Framework for the Supervision of Internationally Active Insurance Groups (ComFrame) and Global Systemically Important Insurers (GSIIs)).

Equipped generally with comprehensive risk underwriting and capital management skills, insurance companies today are capable of supplying products of higher quality and at a more competitive price than ever. Working with their reinsurance partners and intermediaries, insurers keep introducing innovative risk financing programmes which, for instance, increasingly involve non-traditional risk financiers (e.g. captive and selfinsurance), underwriters (e.g. capital market investors), underlyings (e.g. natural catastrophes in developing economies) or clienteles (e.g. takaful and microinsurance consumers). They are building more stringent corporate governance standards and internal risk management policies for long-term business sustainability and firm value enhancement. Enterprise risk management is now a norm rather than an exception in the industry. Consumers, too, better understand the products than ever and can even assist governments and insurers in filling gaps in insurance coverage supplies.

The insurance market is dynamic and constantly changing, and even volatile in times of crisis. Its operation thus relies on an adequate supply of financial and human capital. Of the two capitals, the industry seems to be in a better shape with regard to financial capital management. Stringency in insurance regulation, plainly for the protection of policyholders but intrinsically as an attempt to keep the market less volatile and to minimise insurer bankruptcy risk, makes the industry fairly attractive to investors. For example, the capital surplus of the U.S. non-life insurance market was more than $\$ 550$ billion in December 2011, a significant increase from $\$ 437$ billion in early 2009 , while the premium-to-surplus ratio remained around 0.80 .

We observe, however, material issues in human capital management in the industry. The U.S. industry, again as an example, experienced human capital growth at a rate lower than the national average during the 12-month period ending in October 2012. It experienced modest manpower growth in non-life ( 0.17 per cent), health and medical $(0.30$ per cent $)$, reinsurance $(0.36$ per cent) and intermediary $(0.71$ per cent) businesses. During the same period, life business even lost 0.30 per cent of its manpower. ${ }^{1}$ A report by the Insurance Information Institute ${ }^{2}$ about human capital management issues in the U.S. during 1990-2011 notes that the industry had: a volatile and gradualdownward shift in the non-life market, a fast decrease in the life and reinsurance markets; and a gradual, positive growth in the health and medical market, the agency and brokerage market and, with some volatility, in the claims management market. In sum, of all lines, the institute observes more signals of volatility than stability in the U.S. insurance labour market.

\footnotetext{
${ }^{1}$ U.S. Bureau of Labor Statistics Database (2012).

${ }^{2}$ Insurance Information Institute (2012).
} 
As elaborated further in this paper, the supply of workers - especially talent workers with a passion for risk management and insurance (RMI) - remains a critical issue for insurers of all sizes in all economies. Unlike for underwriting and investment operations, we do not have explicit or standardised valuation functions for human resources. We treat them as intrinsic capital that simultaneously supports the entire functional areas of the insurance company. The value may not be seen clearly and some employers even fall in love with the "talent paradox myth" according to which high unemployment rates create a talent surplus in the labour market. In reality, talent shortages in key business units is what we should expect ${ }^{3}$ at such times, and an entity experiencing a "brain drain" - the departure of high-performing talent-would face a critical "human capital risk". 4 A solution to this problem would be to include this risk as part of the entity's ERM risk portfolio ${ }^{5}$ and to have the Chief People Officer (CPO) as an Enterprise Risk Management Committee member.

The human capital attraction and retention challenge is becoming acute due to a combining effect of social, demographic, economic and industry-specific factors. Population ageing is certainly one such factor. The fact that, due to the general public's limited knowledge about insurance, the business is not the younger generation's preferred career choice is another. People tend to view insurance merely as expenditure rather than as financing for current and future wealth preservation. Pedagogical trends in tertiary business education exacerbate the industry's problem. Furthermore, there is human capital obsolescence risk that we should not underestimate. This paper focuses on these important issues and attempts to suggest working solutions.

The structure of this paper is as follows. The next two sections investigate the issues using two perspectives. The first is macrospective and deals with demographic changes - population ageing in particular - in the global, regional and selected country markets. The third section is microspective and covers the issues within the insurance industry. In the fourth section, we examine the supply of future talent workers by educational institutions based on an analysis of RMI curricula in sample universities. A summary of the findings and recommendations is presented in the final section. Unless otherwise noted, the study scope is international.

\section{Demographic shift and supply of manpower: A public policy issue}

Population ageing along with low fertility rates has become a major risk globally, and the assumption that the supply of young human capital will remain sufficient for an economy to sustain its growth may no longer hold in the future. Eurostat ${ }^{6}$ forecasts that 80 per cent of the European workforce growth occurs in the $50+$ age group and that by 2050, 40 per cent of Europe's total population and 60 per cent of its working

\footnotetext{
${ }^{3}$ Deloitte (2010).

${ }^{4}$ Deloitte finds that talent shortages would be most serious in research and development (R\&D) and executive leadership. Other pressing talent concerns they find include competing for talent in emerging economies, developing leaders and success plans, retaining employees at all levels, and managing and developing training programmes.

${ }^{5}$ Zurich American Life Insurance Company (2012).

${ }^{6}$ Eurostat (2004).
} 


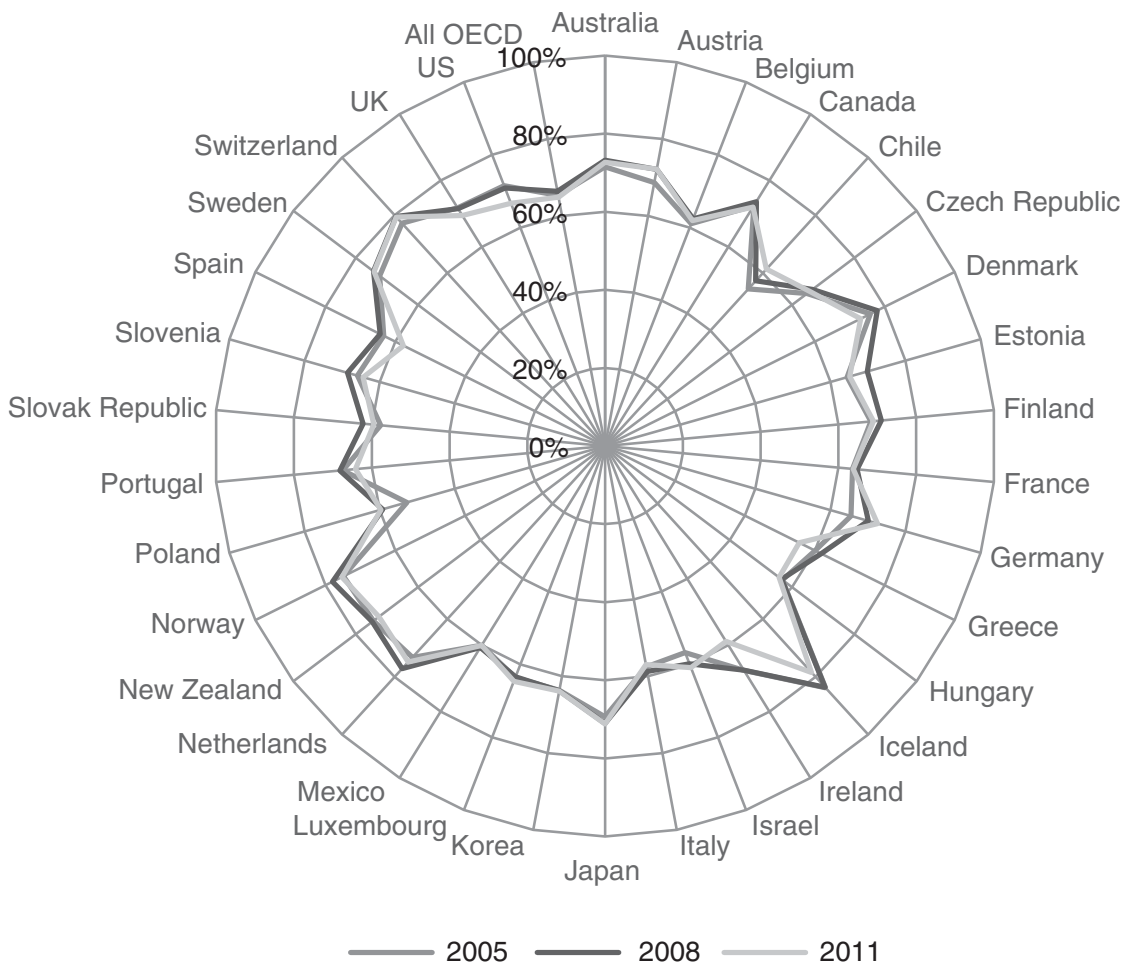

Figure 1. Employment-to-population ratio development in OECD countries.

Source: Constructed using data from OECD StatExtracts (2012).

age population are likely at least 60 years old. The health-care, manufacturing, energy and public sectors may suffer most from this population exodus. The grey dependency ratio (worker to retiree ratio) is expected to drop from 4.62 in 2010 to 3.02 in 2030 in the aggregate of the Organisation for Economic Co-operation and Development (OECD) countries. ${ }^{7}$ Developing economies are affected as well. During the same 2010-2030 period, Brazil is expected to have a drop in the ratio from 9.81 to 5.32, Russia from 5.86 to 3.48 , India from 11.37 to 7.33 and China from 8.71 to 4.08 .

As depicted in Figure 1, the employment-to-population ratio in OECD countries dropped from 65.29 per cent in 2005 to 64.85 per cent in 2011. Of course, some OECD countries experienced growth (e.g. Austria, Chile, Germany, Israel and Poland), some experienced a reduction (e.g. Greece, Iceland, Ireland, Portugal, Spain and the U.S.) and others showed small changes. As shown in Figure 2, the ratios in the selected Asian countries dropped by as little as 0.8 per cent in Singapore and as much as 6.3 per cent in Thailand during 1991-2011. China also showed a reduction of 4.2 per cent, probably in part due to the one-child policy that the government introduced in $1979 .{ }^{8}$ The

\footnotetext{
${ }^{7}$ Strange and Barley (2008).

${ }^{8}$ Banister et al. (2010) identify the cumulative, combining effects of low fertility rates - driven significantly by the one-child policy - and rising life expectancy as the root of population ageing in China.
} 


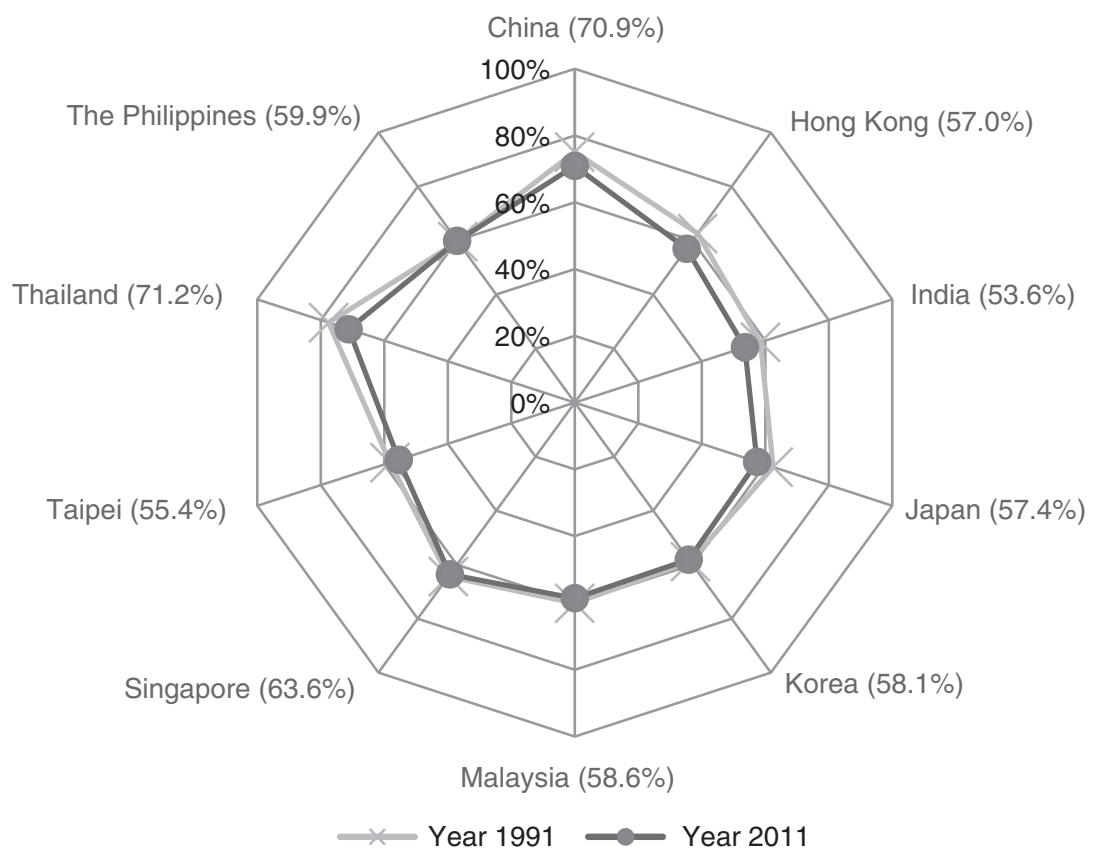

Figure 2. Employment to population ratio development in Asia (aged 15+).

Source: Constructed using data by the Asian Development Bank (2012).

Philippines was the only country with growth, the Asian Development Bank ${ }^{9}$ finds.

Korea Research Institute for Vocational Education and Training (KRIVET) ${ }^{10}$ presents a more detailed finding for Korea. It estimates that the size of the productive population (aged 15-64) in Korea will shrink by around 0.9 million between 1990 and 2050. As depicted in Figure 3, this transformation likely results in a rise of the 50-64-year-old age group to 40.9 per cent of the total productive population in 2050 . The actual percentages were 16.1 per cent in 1990 and 25.0 per cent in 2010 . The size of the aged 15-24 years group is expected to shrink during the study period.

Governments and intergovernmental agencies are preparing for an exodus of older workers, especially baby boomers, and have introduced several long-term strategic plans. For example, the European Council ${ }^{11}$ adopted the Lisbon Agenda-albeit declared incomplete in the target year of 2010 - as a means to improve European policies in part for competition, trade, employment and education at the national and European levels. ${ }^{12}$ Its sequel, Euro 2020, targets, among others: a 75 per cent

${ }^{9}$ Asian Development Bank (2012).

${ }^{10}$ Korea Research Institute for Vocational Education and Training (KRIVET) (2012).

${ }^{11}$ European Council (2000).

12 The European Council (2000) wished to make the EU "the most competitive and dynamic knowledgebased economy in the world capable of sustainable economic growth with more and better jobs and greater social cohesion". 


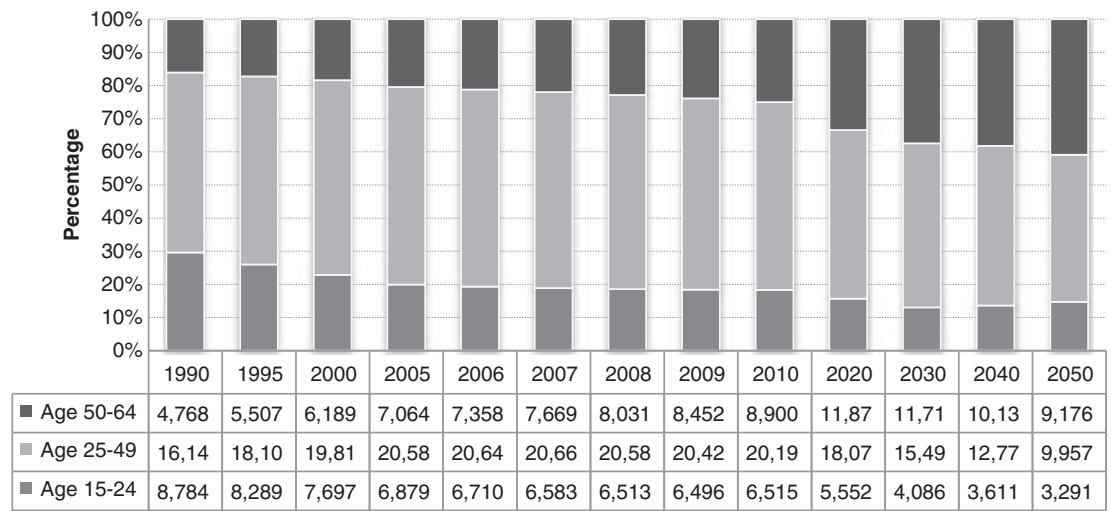

Figure 3. Estimates of the productive population by age group in Korea.

Source: KRIVET (2012) and the OECD (2011).

employment rate of the population aged 20-64, a reduction of the share of early school leavers to 10 per cent or below and an increase in the share of the population aged 30-34 having completed tertiary education to at least 40 per cent. ${ }^{13}$

The U.S. Government Accountability Office ${ }^{14}$ reports that around 30 per cent of federal employees at year end 2011 would become eligible for retirement by $2016 .^{15}$ Cyber-security, acquisition management and foreign language capabilities are the main areas of skills shortage in the public sector. In response, the U.S. created in 2002 the $\mathrm{CHCO}$ Council, comprising the chief human capital officers in 24 federal agencies plus the White House OPM director. It also introduced the Pathway programmes in 2012, which consist of the internship programmes for students in high schools, colleges and other qualifying institutions and the recent graduate programmes for those with an associate degree or higher.

Promotion of the employment of older people would be an additional working solution to the ageing population problem. Conversely, the practice of mandatory retirement would reduce the motivation of not only older workers near retirement, but also middle-aged workers who fear being unable to find a new job simply because of their age. ${ }^{16}$ Japan, a country where mandatory retirement is a dominant practice, has experienced a 20 per cent reduction of labour force participation of the 60-69 age group. ${ }^{17}$

13 European Council (2010).

${ }^{14}$ U.S. Government Accountability Office (2012).

${ }^{15}$ Interestingly, the Office of Personnel Management (OPM, 2008) finds that the median number of years that federal employees would stay with the government after first becoming retirement-eligible is 4 years, although nearly 25 per cent might remain for 9 years or more.

${ }^{16}$ Sun Life Financial (2011) finds that only 35 per cent of Americans plan to retire by age 67. An EBRI (2012) study shows that 62 per cent of American workers identify debt as a key factor that complicates their retirement outlook.

${ }^{17}$ Seike et al. (2012). 


\section{Supply of talent workers}

The Lloyd's ${ }^{18}$ Risk Index reports "a shortage of talent and skills" as the second most critical risk in 2011 that businesses face globally, a significant change from its ranking as an average risk (the $22^{\text {nd }}$ out of 50) in the 2009 survey. ${ }^{19}$ It reports that 70 per cent of respondents in Asia and the Pacific rank the risk as most critical in the 2011 survey. By country, Japan faces a severe demographic deficit with near-zero population growth and rapid ageing of the population. In Germany, this problem, known as Fachkräftemangel, is so severe that the country now depends in part on young, foreign immigrant workers to fill the gap. In contrast, India is safe with one of the world's youngest population (70 per cent of the people under age 35). The Lloyd's Risk Index reports that less than 50 per cent of the respondent companies in all regions are prepared to manage talent and skills shortage problems.

Further differences in attracting and retaining workers by skills level exist. From reconstructing survey findings by Towers Watson ${ }^{20}$ as presented in Table 1, we find that 65 per cent of employers express difficulty in attracting critical-skill employees as compared with 25 per cent for all employees. Within the critical-skill worker category, the difficulty is felt more greatly in fast developing economies, such as China/India (84 per cent) and Brazil (81 per cent), than in developed economies, such as Ireland/ Spain (49 per cent) and the U.S. (52 per cent). Similar patterns in employers' difficulty in retaining talent workers are observed. The global retention average for talent workers is 49 per cent as compared with 21 per cent for all workers. Again, the problem is felt greater in rapidly developing economies such as India/China (81 per cent) and Brazil (65 per cent), than in developed economies such as Ireland/ Spain (29 per cent) and the U.S. (31 per cent).

A number of academic papers have examined human capital management, talent development and labour market issues in general. For example, Harter et al. ${ }^{21}$ develop $Q^{12}$ Meta Analysis to examine the relationship between employee engagement and performance in 125 and 152 respondent organisations to Gallup's 1999 and 2009 surveys, respectively. ${ }^{22}$ Using the following model (simplified):

\section{Per-person Productivity $=$ Talent $\cdot \Sigma($ Relationship, Right \\ Expectation, Recognition/Reward),}

they find presence of some generalisability between employee engagement and customer loyalty, profitability, productivity, employee turnover and safety outcomes. Their 2009 study shows that business units in the top $50^{\text {th }}$ percentile on employee

\footnotetext{
${ }^{18}$ Lloyd's (2011).

19 The most critical risk was "loss of customers/cancelled orders" and "cost and availability of credit" in the 2011 and 2009 surveys, respectively.

${ }^{20}$ Towers Watson (2010).

${ }^{21}$ Harter et al. (1998 and 2009).

${ }^{22}$ The 2009 Gallup survey includes four companies, 3,104 business units and 41,358 respondents in the insurance industry. It covers 21 other financial services companies.
} 
Table 1 Employee attraction and retention difficulties by region

\begin{tabular}{|c|c|c|c|c|c|c|c|c|}
\hline & $\begin{array}{c}\text { Global } \\
(\%)\end{array}$ & $\begin{array}{l}\text { Chinal } \\
\text { India } \\
(\%)\end{array}$ & $\begin{array}{c}\text { Other } \\
\text { Asia-Pacific } \\
(\%)\end{array}$ & $\begin{array}{c}\text { Ireland/ } \\
\text { Spain } \\
(\%)\end{array}$ & $\begin{array}{c}\text { Other } \\
\text { Europe } \\
(\%)\end{array}$ & $\begin{array}{c}\text { Brazil } \\
(\%)\end{array}$ & $\begin{array}{c}\text { Canada } \\
(\%)\end{array}$ & $\begin{array}{l}\text { U.S. } \\
(\%)\end{array}$ \\
\hline \multicolumn{9}{|l|}{ Problems attracting } \\
\hline Critical-skill employees & 65 & 84 & 78 & 49 & 62 & 81 & 61 & 52 \\
\hline Top-performing employees & 61 & 76 & 71 & 52 & 67 & 69 & 57 & 45 \\
\hline High-potential employees & 56 & 68 & 70 & 47 & 58 & 67 & 54 & 40 \\
\hline All employees & 25 & 36 & 41 & 22 & 19 & 30 & 22 & 15 \\
\hline \multicolumn{9}{|l|}{ Problems retaining } \\
\hline Critical-skill employees & 49 & 81 & 69 & 29 & 44 & 65 & 35 & 31 \\
\hline Top-performing employees & 45 & 77 & 63 & 22 & 41 & 67 & 35 & 25 \\
\hline High-potential employees & 45 & 75 & 60 & 29 & 43 & 64 & 38 & 25 \\
\hline All employees & 21 & 39 & 39 & 14 & 12 & 26 & 12 & 11 \\
\hline
\end{tabular}

Source: Reconstructed using Towers Watson (2010).

engagement double their probability of success as compared with those in the bottom $50^{\text {th }}$ percentile. $^{23}$

De Grip ${ }^{24}$ proposes that human capital management is to transform us towards a "knowledge-based society by means of lifelong learning" and we face the risk of human capital obsolescence. The obsolescence comprises technical obsolescence and economic obsolescence. The former can be caused by wear (e.g. natural ageing process, illness or injury) or atrophy (no or insufficient use of skills). The latter consists of jobspecific obsolescence caused by new skill requirements due to technological and organisational developments, sector-specific obsolescence resulting from the shift in employment in an occupation or economic sector and firm-specific obsolescence arising from displacement in sectors even with stable employment. Analysing EU labour market data, he finds that employers as well as workers may not invest in training when the workers are exposed to one or more of these obsolescences.

Bontis and Serenko ${ }^{25}$ assume that the intellectual capital of an organisation comprises human, structural and relational capital. Human capital is about the competencies, tacit experiences and overall knowledge-base of individuals. Structural capital is all the knowledge within the organisation that is not in the minds of workers. Relational capital is the knowledge embedded in relationships with customers and others in the chain of business. From empirically testing a model with intellectual capital along with other factors (e.g. managerial leadership, employee motivation and business performance), they find that strategic management of intellectual capital is the most important driver of the organisation.

${ }^{23}$ From employing $Q^{12}$ in 2002, Mutual of Omaha (U.S.) finds that its business units in the top quartile operated at 6 per cent below their projected operating costs, but the units in the bottom quartile were almost 1 per cent above their projected operating costs (Welch, 2004). Other talent management programmes include but are not limited to (Lean) Six Sigma and Business Process Outsourcing (BPO).

${ }^{24}$ De Grip (2004).

${ }^{25}$ Bontis and Serenko (2009). 
As further elaborated in this paper, we propose that the disparity in academic programmes and industry human capital skills needs can also inflate obsolescence risk. The disparity may be soft skills-specific (e.g. oral and written presentation), knowledge-specific (e.g. the breadth of courses in the academic major), if not both. The narrower the disparity, the lower the obsolescence risk management cost, ceteris paribus.

\section{Search for talent workers in the insurance industry}

The insurance industry has a relatively highly stratified workforce, ranging from lower skilled employees to highly skilled workers. Its business, especially the reinsurance segment, has long been international, thus making the human capital management issue in the industry broader in scale and scope than in many other industries.

We find population ageing in the industry. Sweet et al., ${ }^{26}$ for instance, examine the labour market in the U.S. finance and insurance sector and come up with the following two key findings.

- The percentage of workers at the 55-64 and 65 + age groups in the sector rose by about 38 and 10 per cent, respectively, during the 2000-2007 period. ${ }^{27}$ The changes in the finance and insurance sector seem to be greater than the changes in the national average. Although not shown in the figure, the sector is disproportionately comprised of female workers (e.g. 59.3 per cent in 2007).

- The employers in the sector are well aware of employees' career plans, work preferences and retirement rates, thus likely being better prepared for the ageing workforce than the employers in other sectors. ${ }^{28}$ The most frequently noted concern of the employers in the finance and insurance business was recruiting competent applicants, especially with management, sales/marketing or legal skills.

Jacobson $^{29}$ finds that U.S. insurers face recruiting challenges for-in the order of difficulty - actuaries, executives, technology specialists and underwriters (particularly commercial non-life underwriters). McKinsey \& Company ${ }^{30}$ finds that the number of employees aged $55+$ increased by 74 per cent (as compared with a 45 per cent increase in the aggregate of all employees) in the U.S. insurance industry during the 10-year study period ending in 2008. It also finds that 20 per cent of the insurance employees

\footnotetext{
${ }^{26}$ Sweet et al. (2010).

${ }^{27}$ Their study is based on the total population in the finance and insurance sector, including 317,800 insurance sales agents (accounting for about 5 per cent of the sector population) reported in 2008 by the U.S. Bureau of Labor Statistics.

${ }^{28}$ Specifically in the finance and insurance sector, 51 per cent of the companies have developed succession plans (as compared with 35 per cent of employers in other sectors), 51 per cent of them have projected retirement rates (as compared with 21 per cent), 55 per cent of them have evaluated competency sets of current employees (as compared with 49 per cent), 48.9 per cent of them have assessed anticipated skill needs (as compared with 43 per cent), and 35 per cent of them have identified employee career plans and work preferences (as compared with 21 per cent).

29 Jacobson (2010 and 2012).

${ }^{30}$ McKinsey \& Company (2010).
} 
were near retirement age (as compared with 15 per cent in the entire financial services sector) and the proportion of near-retirement insurance workers would rise to 25 per cent by 2018. Reinsurers and brokers are at greater risk than personal or commercial line carriers. In the aggregate of all business lines, U.S. insurers are exposed to greatest risk in securing underwriters.

The findings by Deloitte ${ }^{31}$ give us more detailed information about the U.S. At the time of the survey: 70 per cent of insurance company adjusters were aged $40+; 88$ per cent of CPCU Society members were aged 40 or older; and the average age of insurance agents was 47 - nearly 60 per cent of them were over the age of 45 . The number of CPCU candidates dropped from 52,500 in 1992 to 18,000 in 2004. It went up to 22,451 in 2006 but still stays well below its all-time high record. The non-life insurance industry had 101,000 underwriters in 2004 and the demand is expected to reach 109,000 by 2014. Assuming an annual growth rate of 8 per cent and an aggregate estimated attrition rate of 15 per cent, the industry would need 23,000 new underwriters to fill the gap. The industry would also need to fill 84,000 new claims adjusters by the end of the 10-year period.

Korea experiences some shortage of workforce in the financial services sector. ${ }^{32}$ Kwon et $a l .{ }^{33}$ forecast that the insurance and reinsurance markets (less pension and annuity markets) would have a total of 322,000 workers in 2020 , thus needing 1,000 new workers per annum to support the growth. The pension and annuity markets are expected to grow at a faster rate (5.5 per cent per annum) to a total of 19,000 employees in 2020 . Lee ${ }^{34}$ finds that the Korean industry is in critical need of specialists in product development, underwriting, pricing, and marketing and intermediary services.

\section{Reputation risk of the insurance industry: Before vs after}

A study of human resources management would be incomplete without an analysis of the industry's attractiveness to new and existing employees. In other words, what is the reputation of the industry to future and current workers as well as to the public? We note here two interesting and very important sides of the industry's reputation.

On the one hand, we know that insurance premiums are greater, at least in theory, than the attached expected value of the loss, insurance coverages are finite in non-life insurance, and consumers - particularly individuals and small businesses - tend to view that premiums are irrecoverable expenditure rather than capital outlays against future losses. Consumers often do not fully understand the insurance products they purchase $^{35}$ and their ability to reason financial situations is not always objective. ${ }^{36}$ The public - including high school and college students - often poorly understands

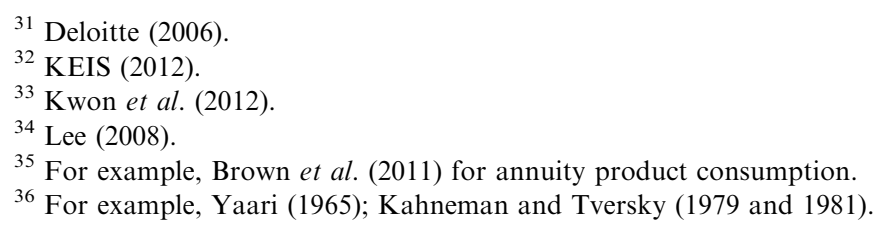


the benefits of insurance and the role the industry plays. Many "Generation Y-ers" (birth years 1982-1993) view jobs in the industry as "rigid and slow-paced", which may contradict their workplace values. ${ }^{37}$ High-profile scandals in the industry reduce people's perception of its integrity, especially those who prioritise professional ethics and social responsibility over other business goals. The "poor reputation" along with a "limited understanding among students of the industry's career opportunities" and a "limited pool of trained talent" are the three major challenges the U.S. non-life insurance industry faces. ${ }^{30,38}$

On the other hand, studies find that insureds and, to a certain degree, the public are likely to view insurance service positively and insurance premiums as investment against future financial adversity once they have benefited from insurance claims or hear the news about the role the industry plays immediately after, say, a man-made or natural catastrophe. Several studies support this contention. For example, surveys conducted by the Reputation Institute ${ }^{39}$ on the insurance industry and company reputation find the following.

- Industry reputation. ${ }^{40}$ The insurance industry earned a reputation preference score of 61.60 and was ranked $17^{\text {th }}$ out of 25 industries in the 2012 survey. ${ }^{41}$ The score implies that the likelihood consumers would buy insurance products is 41 per cent (as compared with the highest possibility of 64 per cent for the industries with a score of $80+$ ); that they would recommend the products is 37 per cent (as compared with 59 per cent); that they would work for an insurance company is 37 per cent (as compared with 47 per cent); and that they would invest in the industry is 31 per cent (as compared with 35 per cent). Improving the reputation by 5 score points would lead to a 6.1 per cent increase in the likelihood of consumers' recommendation of the industry. No insurance companies are found in the lists of the Global Top 50 Companies, European Top 50 Companies and Asian Top 50 Companies generated by the institute.

Within the U.S., the insurance industry's reputation ranked $11^{\text {th }}$ out of a total of 18 industries. $^{42}$ Among the top 100 preferred U.S. companies, we find Berkshire Hathaway (ranked $\left.16^{\text {th }}\right)$, State Farm $\left(53^{\text {rd }}\right)$, Hartford Financial Services $\left(62^{\text {nd }}\right)$, MetLife $\left(65^{\text {th }}\right)$, Chubb $\left(74^{\text {th }}\right)$, New York Life $\left(77^{\text {th }}\right)$, Aflac $\left(80^{\text {th }}\right)$, Allstate $\left(86^{\text {th }}\right)$, Liberty Mutual $\left(89^{\text {th }}\right)$, Travelers $\left(92^{\text {nd }}\right)$, Prudential $\left(94^{\text {th }}\right)$ and Assurant $\left(100^{\text {th }}\right)$.

- Workplace preference. The institute publishes lists of companies preferred by students and by current workers in selected countries. Our search for insurance companies in the U.S., the U.K., France, Germany, Japan, Brazil, Russia, India and

\footnotetext{
${ }^{37}$ Deloitte (2007).

${ }^{38}$ See also Cole and McCullough (2012) for a summary of the discussions at the 2011 Insurance Education and Career Summit (U.S.). The summit participants agree that the main obstacles are industry reputation, resources and recruitment.

${ }^{39}$ Reputation Institute (2012a, b).

40 The Reputation Institute uses three main sources of information for the measurement: respondents' direct experience (products, customer service, investment and employment); information from the company (advertisement, public relations, marketing and social responsibility); and information from other sources (e.g. media and experts).

${ }^{41}$ The banking and other diversified financial services industries are ranked $20^{\text {th }}$ and $21^{\text {st }}$, respectively.

42 The banking and other diversified financial services industries are ranked $17^{\text {th }}$ and $18^{\text {th }}$, respectively.
} 
China came out empty-handed except for Japan. Japanese students ranked Dai-ichi Life Insurance Company in the $22^{\text {nd }}$ place and Meiji Yasuda Life Insurance Company in the $27^{\text {th }} .{ }^{43}$ We separately conducted a search for insurance companies that currently-employed workers prefer and find none in the lists of the U.S.' Top 100, the U.K.'s Top 30, Germany's Top 50, France's Top 50 and China's Top 100.

The above findings indicate that the insurance industry, as well as most insurance companies, has not attained a high reputation or wide recognition in most of the countries the Reputation Institute surveyed. Nevertheless, this perception may not be necessarily global, as we find preference among students for selected insurance companies in the U.S. and preference among workers for two life insurance companies in Japan.

Spencer Educational Foundation conducted a small sample survey with its 2010-2012 scholarship recipients. ${ }^{44}$ Those U.S. students respond that the most popular reason for selecting an RMI programme is job opportunities ( 56 per cent), followed by opportunity for advancement (47 per cent) and industry stability and job security (44 per cent). Their areas of interest are risk management (37 per cent), underwriting (27 per cent) and sales and marketing (19 per cent). Eighty-six per cent of them plan to earn a professional designation, such as $\mathrm{CPCU}$ or associate in risk management. The most attractive employers for them are those offering internal opportunities for advancement (78 per cent) or formal mentoring programmes (16 per cent). McKinsey ${ }^{30}$ also finds from its own survey of RMI alumni in the U.S. that the respondents agree the industry offers a good work-life balance (83 per cent), provides frequent intellectual challenges (93 per cent) and generates significant value to society (94 per cent).

For Korea, the KEIS ${ }^{45}$ conducted an online survey of 8,294 students in two- and four-year colleges. Of the respondents, 59.1 per cent are male, 72.2 per cent in the 19-24 age group and 78 per cent planning on full-time employment after graduation instead of, for example, going to a graduate school. The KEIS reports that 4.59 per cent of all respondents wish to enter the financial services sector. ${ }^{46}$ The percentage rises to 6.5 per cent for the fourth-year student group. The respondents choose - in the order of preference - government agencies, government-run companies, large companies (including holders of insurance subsidiaries) and foreign companies as their dream employers. The preference to the financial services sector rises to 10.1 per cent for the respondents in the last two school years and to 22.08 per cent if they also study social science or business. The respondents note a match with the academic major (41 per cent), self-development ( 26 per cent), job security (13 per cent) and salary (10 per cent) as important job-search factors. Separately, Jung ${ }^{47}$ surveyed current employees in Korea to find that relatively higher salary and better fringe

${ }^{43}$ This series of surveys involves 203,333 students in 978 universities, including 2,261 students in 59 universities in Japan.

${ }^{44}$ Business Insurance (2012).

${ }^{45}$ KEIS (2008).

${ }^{46}$ The industries found to be more attractive to the respondents are: managerial, accounting and other office work (14.63 per cent); entertainment and broadcasting (13.11 per cent); education and research (11.24 per cent); IT and telecommunications ( 9.04 per cent); managerial work (8.61 per cent); and medical and medicinal profession $(7.37$ per cent).

47 Jung (2012). 
benefits make the jobs in the public sector and large companies more attractive and such attractiveness rises more than proportionally as they gain more work years.

\section{Talent worker management in the insurance industry}

What would be the strategic thinking that employers in the insurance industry need to attract and retain talent workers? Towers Watson ${ }^{48}$ finds that all workers - inclusive of high-potential performers - in the U.S. and Canada rank job security, followed by base pay and health-care benefits as key factors. High-potential performers also rank job security as the most critical factor, but the second most critical factor is "career development opportunities" for those in the U.S. and "health-care benefits" for those in Canada. A subsequent survey by Towers Watson ${ }^{49}$ confirms these findings. Stewart ${ }^{50}$ reports that formalised talent management and succession planning processes is relatively recent (i.e. the mid 2000s) for most European insurance companies.

Attraction and retention of talent employees is an issue for insurance companies in the mergers and acquisitions (M\&A) market. As solutions, they use lateral moves of employees to new roles (used by 54 per cent of the respondents), participation in integration task forces (46 per cent), personal outreach by leaders or managers (43 per cent) and relocation ( 37 per cent). ${ }^{51}$ They tend to avoid using retention bonuses (21 per cent), promotions (18 per cent) or equity grants (10 per cent) ${ }^{52}$

Another survey Sweet et al. ${ }^{53}$ in which insurance and finance company employees are grouped together gives a different picture. From analysing data from the 2009 Talent Management Study to which 696 organisations-including 45 insurance and finance companies - in the U.S. participated, they find that, as compared with the employers in nine other sectors:

- Nine out of 10 employees in the finance and insurance sector are somewhat, if not fully, satisfied with their job.

- Employees in the sector consider certain job incentives as important or very important, for example: work interest (98.2 per cent vs 94.7 per cent in other sectors), security (94.6 per cent vs 93.3 per cent), career advancement (89.1 per cent vs 87.7 per cent), helping each other ( 88.3 per cent vs 86.2 per cent) and social usefulness (86.5 per cent vs 84.8 per cent).

- Skills in short to a moderate/great extent include but are not limited to: managerial skills (37.8 per cent vs 37.5 per cent in other sectors), sales and marketing skills (37.8 per cent vs 27.6 per cent), legal skills (31.7 per cent vs 29.3 per cent) and technical computer skills (18.2 per cent vs 22.3 per cent).

\footnotetext{
${ }^{48}$ Towers Watson (2011).

49 Towers Watson (2012).

${ }^{50}$ Stewart (2009).

51 Dean and Cianni (2011).

52 The study is based on a Towers Watson survey to which 15 of 17 respondents agreed that "acquiring talent and new capacities" is a key success element in M\&A transactions.

${ }^{53}$ Sweet et al. (2010).
} 
- Talent assessment activities and programmes in the sector cover, for example: competency of current employees (55.6 per cent vs 49.9 per cent in other sectors), supervisor's staffing plan and capability (51.1 per cent vs 49.9 per cent), succession plan (51.1 per cent vs 35.1 per cent), retirement rate projection (51.1 per cent vs 21.6 per cent) and skills needing in the future (48.9 per cent vs 43.9 per cent).

- Few employers in the sector believe they have too many human resources development programmes. Only one in four of the employers think they have too few programmes.

For Korea, $\mathrm{Kim}^{54}$ analyses the Korea Network for Occupations and Workers (KNOW) database from 2001 to 2011 to examine changes in job competency and to identify the core skills that students and job seekers are expected to have in each of 25 occupation groups. ${ }^{55}$ Key findings from his study about the Financial Services Occupation Group are summarised below. ${ }^{56}$

- Cognitive abilities. The group ranks $4^{\text {th }}$ highest for reasoning, critical thinking and other cognitive abilities. Other groups with high cognitive abilities include natural/ social science researchers, managers and high government officials, social and religious workers and law enforcement officials.

- Social perspectives. The group ranks $5^{\text {th }}$ in social skills. Other groups with a higher rank include social and religious workers, managers (and high government officials), natural/social science researchers and medical and allied professionals.

- Management knowledge. The group ranks highest for this criterion, followed by groups encompassing managerial, marketing, accounting and clerical professions.

- Communication skills. The group ranks $4^{\text {th }}$ highest for this skill set. Ranked higher than this group represents jobs in law enforcement, information technology and natural/social science research fields.

- Technical skills. The group is shy below the average level of technical skills of all occupation groups. Other groups with a similar level include jobs in construction, transportation, food processing, and social work and religion.

- Physical/sensory skills. The group does not require much of physical or sensory skills. In fact, the study finds this group at the bottom of all other groups for this skills need. A similar finding is made for the accounting and clerical worker group.

- Engineering skills. The group ranks $19^{\text {th }}$ for engineering skill requirement. Law enforcement, accounting clerical jobs rank close to this group. This contrasts to the information technology, electronic and construction groups that require highest engineering skills.

\footnotetext{
${ }^{54} \operatorname{Kim}(2012)$.

${ }^{55}$ Similar to the one developed by the O*NET, the KNOW database is based on annual surveysparticularly since 2006 - of: knowledges, skills, abilities (KSAs); interests, general work activities (GWAs); and work context. The $\mathrm{O}^{*} \mathrm{NET}$ is a database of worker attributes and job characteristicsincluding several insurance professionals - in the U.S.

${ }^{56}$ Financial services professionals (e.g. underwriters, claims specialists, investment analysts, product developers and stock market dealers), front and back office staff, and intermediaries (e.g. agents and brokers) belong to KNOW's "Financial Services Occupation Group".
} 
Plans to attract, train and retain human capital are certainly for investment. In fact, Deloitte $^{31}$ finds from examining Fortune's "100 Best Companies to Work for" and Hewitt's "Top 20 U.S. Companies for Leaders" in 2005 that the average return on investment of those leading companies was always much higher (189 per cent) than that of S\&P 500 (24 per cent) and Russell 3000 during 1997-2004. We now investigate the main suppliers of new talents; that is, academic institutions.

\section{Supply of new talent workers by academic institutions}

The level of education globally continues to rise. The full- and part-time education enrolment rose by 10.1 per cent for the aged 20-29 in OECD countries during $1995-2010 .^{57}$ The average for this age group was 27 per cent in 2010, and more women than men were in education in this group. ${ }^{58}$ An earlier report by the OECD ${ }^{59}$ shows that 1.4 per cent of the U.S. population aged $40+$ were enrolled as full-time or parttime students in public and private institutions in 2007, as compared with 6.8 per cent of the 30-39 age group and 20.6 per cent of the 20-29 age group.

The share of the population that has attained tertiary education is rising as well. The $\mathrm{OECD}^{57}$ reports 31 and 26 per cent as the average share of this population segment in all OECD and G20 countries, respectively, for $2010 .^{60}$ From examining the data and as presented in Figure 4 for selected countries, we find that the attainment percentage is highest for the aged 25-34 and lowest for the aged 55-64 in most OECD countries. ${ }^{61}$ The figure also shows that attainment of higher education is very likely in Russia but extremely low in Brazil and China. The OECD ${ }^{57}$ projects that 14 per cent of young Chinese will graduate from a college and 18 per cent of them complete a vocational school programme during their lifetime.

Despite the improvement in education in general, we still face challenges in educating students in selected academic fields. The U.S. Department of Education ${ }^{62}$ reports that students' weak competency in mathematics and science are due in part to the rapid pace of change in the U.S. workplace and in the interdependent global economy. Using Deloitte Research data, Athley ${ }^{63}$ examines collegiate education and the skills gap in science and engineering. His findings show that such waning student interest is a greater problem in developed than in developing economies. At the time of survey, 42 per cent of students in China earned undergraduate degrees in science and engineering, while only 5 per cent of the students were in these majors in the U.S. and Germany had been experiencing one-third decline in the science and engineering student pool since 1995 .

\footnotetext{
${ }^{57}$ OECD (2012).

${ }^{58}$ The enrolment rates were 30 per cent or higher in Australia, Belgium, Denmark, Finland, Germany, Greece, Iceland, Korea, the Netherlands, New Zealand, Slovenia and Sweden.

${ }^{59}$ OECD (2009).

${ }^{60}$ These figures include those who attended two-year colleges.

${ }^{61}$ Some exceptions to this trend are found in Finland, Germany, Iceland, Israel and the U.S.

${ }^{62}$ U.S. Department of Education (2000).

${ }^{63}$ Athley (2004).
} 


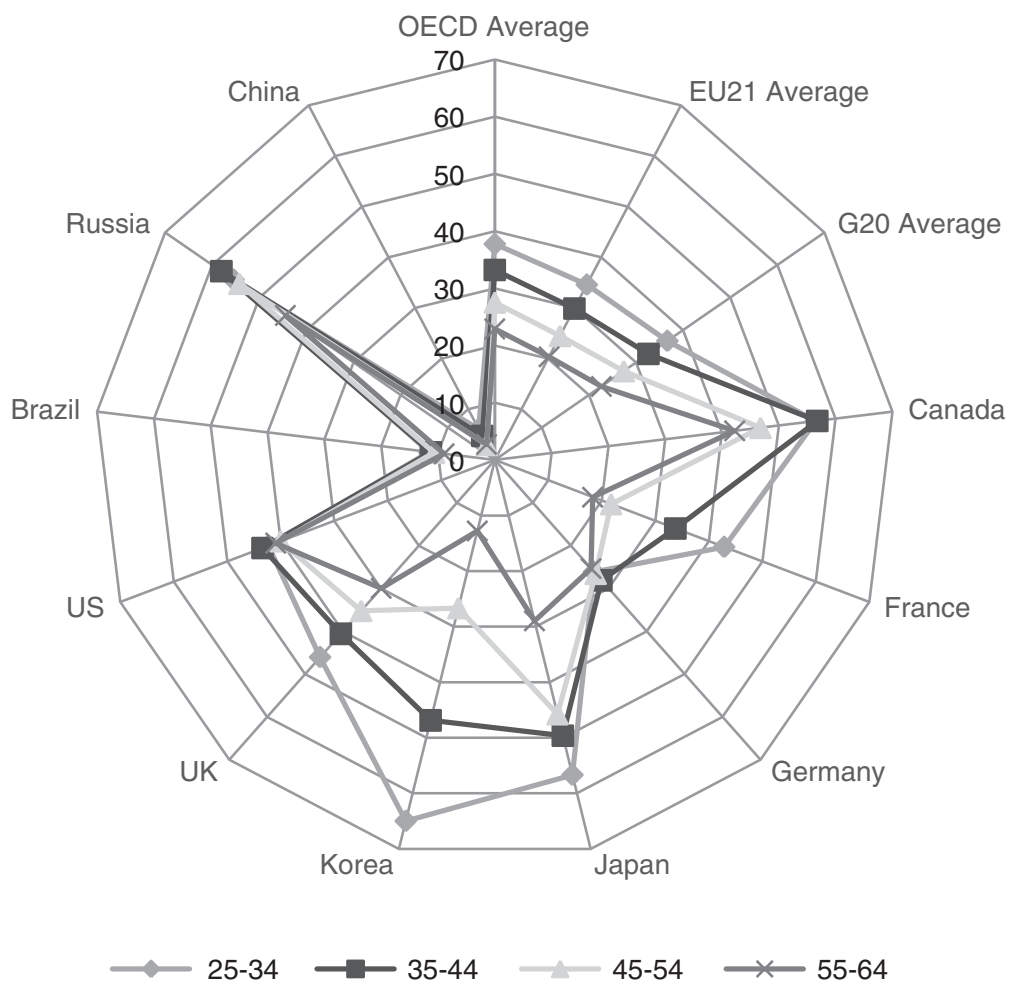

Figure 4. Percentage of population that has attained tertiary education (2010).

Source: Constructed using data from the OECD (2012).

A proxy measure for students' knowledge about insurance can be their financial literacy. For example, a Jump\$tart Coalition survey in 2008 indicates that the financial literacy of U.S. high school seniors fell to its lowest level to an average score of 48.8 per cent. ${ }^{64}$ The average was 57.3 per cent in the 1997 survey. The average score for college students in all school years was 62.2 per cent and was improving for every year of college to 64.8 per cent for seniors. High school seniors who planned to attend a two- or four-year college scored 44.6 and 50.9 per cent, respectively, as compared with the average of 34.9 per cent for the students who did not plan college education. Together, these findings imply the important role of collegiate education in enhancing manpower skills at the national level and as its economy advances.

Today's mainstream suppliers of new entrants to the insurance industry are colleges and universities, particularly those in a bachelor's or master's programme in RMI or actuarial science. ${ }^{65}$ The number of schools offering these programmes varies

\footnotetext{
${ }^{64}$ Mandell (2008).

${ }^{65}$ The $\mathrm{O}^{*}$ NET reports that insurance professional occupations in insurance - for example, underwriting, actuarial work, claims management, financial advice and intermediary service-commonly require
} 
significantly by country. The U.S., for example, is known to have around 70 academic institutions with an undergraduate insurance programme ${ }^{66}$ and 26 institutions offering a master's, doctoral programmes or both in RMI. ${ }^{67}$ These institutions together represented about 10 per cent of the American Assembly of Collegiate School of Business (AACSB) at the time of survey, but the number of RMI programmes is in retreat. ${ }^{68}$ A subsequent study by Gardner and Schmit ${ }^{69}$ confirms that although more than 26,000 students were enrolled in RMI courses at 199 tertiary institutions in the U.S. during the 1992-1993 academic year, the number of institutions offering RMI as an undergraduate major or minor (concentration) was only 58 during the same academic year. They find 19 U.S. institutions offering RMI as a major or minor at the master level and 11 U.S. institutions offering doctoral level studies in RMI.

The Korean Insurance Research Institute lists 28 universities with an undergraduate programme and 19 universities with a graduate programme in RMI and related fields. $\mathrm{Kim}^{70}$ reports 2,425 RMI students and around 100 RMI professors in 2010. In Japan, business schools commonly offer RMI education commonly using European-variant zemis (seminars), thus getting away from establishing a major or minor programme. In 2010 (circa), a total of 656 undergraduate and 131 graduate RMI courses were delivered for 143,149 undergraduate and 1,244 graduate students in Japan. An earlier study ${ }^{71}$ finds that the most popular courses were social insurance, RMI principles and insurance (commerce) law at both undergraduate and graduate levels.

In China, the government designated 10 universities - all top-ranked - for RMI and actuarial science programmes soon after liberalising its insurance market. Other private and public institutions have followed suit. In 2010, China had 87 universities with an undergraduate RMI or actuarial science programme, 47 universities with a graduate programme and 23 universities with a doctoral programme. ${ }^{70}$ Together, they had 20,285 undergraduate students, 1,538 graduate students and 240 Ph.D. candidates. The total number of professors at the assistant level or higher was 1,114 . The number of collegiate RMI programmes is also rising in Taiwan.

The percentage of universities with an RMI programme (or a course in Japan) in all these Far Eastern countries, however, remains around 10 per cent or below of all fouryear institutions in the region. In addition, a number of Asian countries with active insurance operations (including takaful and microinsurance) are known to have only a few institutions (e.g. Hong Kong, India, Malaysia and Singapore) or none (e.g. Bangladesh, Indonesia, Sri Lanka and Vietnam).

We observe another trend in collegiate RMI education. A number of schools in the U.S. now offer an RMI programme along with other related majors or minors, such as finance, banking and, relatively less frequently, real estate. This trend reflects in part a

a substantial amount of work-related skill, knowledge or experience commonly at the universitygraduate level.

66 Anderson (1988).

${ }^{67}$ Gustavson (1991).

${ }^{68}$ Dorfman (1990); Kwon (1999).

${ }^{69}$ Gardner and Schmit (1995).

${ }^{70}$ Kim (2010).

71 Japan Insurance Academy (1999). 
convergence of products and services - thus the need for talent skills - in the financial services sector. Almost all the undergraduate programmes in Korea are hybrid with financial services, international trade or business information technology. A similar observation is made for the graduate programmes in Korea with an exception of one institution. In China, in contrast, we find independent RMI departments as well as several schools of insurance that offer one or more RMI majors (e.g. University of International Business and Economics in Beijing and Southwestern University of Economics and Finance in Chengdu). We also find European institutions with an independent RMI department (e.g. Spain and the U.K.). Germany and Russia often use an insurance chair structure. Not many universities in Latin America-probably except Argentina, Brazil and Mexico-and Africa are known to have an RMI programme.

\section{Collegiate RMI curricula in North America}

We examine RMI programmes in selected universities in the U.S. and Canada. The initial sample universities are drawn from the 56 institutions listed by the American Risk and Insurance Association. After excluding those institutions whose programme structure we cannot confirm or that do not have RMI at least as a minor (concentration or track), we end up with a total of 23 universities. Key findings from this examination are as follows. ${ }^{72}$

- Their programmes commonly require 18-21 credits (or 6-7 courses) for an RMI major. When RMI is offered as a minor, the requirement is often nine credits.

- The first course in RMI (e.g. principles in RMI) is commonly at the junior level, thus not giving students in the business school a chance to learn this academic field often until after them having decided a major. It is a sophomore course in only eight institutions (Ball State University, Gannon University, Illinois Wesleyan University, Olivet College, St. John's University, St. Joseph's University, Temple University and the University of Hartford). (Many of the Asian institutions with an RMI programme are known to have it as a sophomore course.)

- Only three institutions require the principles course for all business school students (Florida State University, St. John's University and Temple University).

- Life insurance, property-liability insurance, (retirement and) employee benefits, risk seminar (or equivalent) and (corporate/enterprise) risk management are the most popular courses - all at the junior or senior level. We also find financial planning (7 institutions), estate planning (6), insurance law (6), insurance operations (8) and commercial risk and insurance (8).

- Only a few universities offer, for example, actuarial (risk) models (4 institutions), alternative risk funding (3), risk theory (1), claims management (1), reinsurance (1), insurance marketing (1) and ethics (1).

- Internship (3-6 credits) is found in 11 institutions (Ball State University, Florida State University, Illinois State University, Indiana State University, St. John's

\footnotetext{
${ }^{72}$ The list is likely incomplete and the listed universities do not necessarily offer all of the courses they list in the programme bulletins.
} 
University, University of Alabama, University of Georgia, University of Louisiana at Lafayette, University of Mississippi, Utica College and Virginia Commonwealth University).

In sum, typical RMI programmes comprise mainly foundation courses, which is in line with the conclusions by Gardner and Schmit ${ }^{69}$ for the U.S. and by Kwon ${ }^{73}$ for Asia-Pacific. A number of U.S. institutions utilise academic internships to help their students generate real workplace experience and make them more marketable. This initiative, on the one hand, reflects the academic community's attempt to nurture students' work skills even before graduation and, on the other, the industry's willingness to train and eventually retain those future talents.

\section{Coordination for human capital development and management}

Population ageing is a serious risk to the insurance industry, and insurers are in critical need of attracting new human capital and retaining current workers. The search for talent workers remains a challenge. The weak reputation of the industry that, correctly or not, the public and students carry needs to be removed to make the industry more attractive to new talent workers. Maintenance and improvement of human resources management programmes is called for to retain existing workers, especially the older ones. Key for the successful continuation of insurance operations includes the human resources management infrastructure via which insurers generate current and future workers with "the right skills, at the right time, place and cost". ${ }^{30}$ Having such infrastructure is equally critical for local and overseas operations. ${ }^{74}$

The field of insurance is not widely known to the public for the reasons alluded to above. It is, however, viewed as attractive to the students studying the subject and as very attractive to the ones who are already in the industry. Therefore, the employers need to find how to broaden the understanding by the young populationparticularly, college-bound high school students and college students in business schools - about the contribution the industry makes to society and the economy and about the professionalism their workers carry. Based on the findings presented earlier in this paper, we offer the following recommendations as solutions to human capital risk.

First, we suggest that the industry be more active in public relations and generate a more positive image of insurance as an academic and professional field. It needs to assist governments in enhancing the financial literacy of the public in general as well as local schools to attract more students to the academic RMI field. The $K-12$ Initiative to foster a more risk-literate society in the U.S., for example, consists not only in helping participating schools develop risk and insurance literacy learning modules but also providing high school teachers with workshops and teaching materials. Insurance companies should also target better consumer education.

\footnotetext{
${ }^{73}$ Kwon (1999).

${ }^{74}$ Cappelli (2008) discusses the merits of internal talent development and management programmes with success cases in the U.S. and abroad (particularly, India and Singapore).
} 
192

Second, we suggest that insurance companies work more closely with qualified local tertiary educational institutions for the adoption of RMI as a major field of study and, in the case of those institutions already with a programme, for coordinated enhancement of students' learning process. The learning can be in class - including curriculum reviews and guest speaker series-and at the workplace-including (academic) internship, mentorship (shadow) programmes and invitations to industry workshops and conferences. We suggest that companies be active in communicating with RMI faculties and vice versa. The Griffith Insurance Education Foundation ${ }^{75}$ additionally recommends executive education, scholarships and funding faculty research and consulting activities. The goal here is to develop more academically viable-and-industry-supported college RMI programmes. Equally importantly, tertiary educational institutions need to constantly review and update their RMI programmes so that their graduates become the future talent with the right soft and hard skills.

Third, employers must continue to review the effectiveness of existing personnel development programmes and update them as and when necessary. They need to review key developments externally in the social, demographic, political, regulatory and economic environments in order to minimise skill- or geography-based job mismatching risk. This work can be done internally or in conjunction with local insurance associations. Collaboration between the public and private sectors is additionally suggested.

Finally, insurance companies need to prepare for talent morbidity across sectors and countries. We recommend a customised (localised) programme that reflects the uniqueness in the environmental factors in each country of operation. We find some guidelines. For instance, Lesser et al. ${ }^{76}$ cite seven keys to succeed in a globally integrated world of business: understanding the demographics and capabilities of the workforce, predicting future labour supply and demand, utilising social networks to increase visibility and application of knowledge across the organisation, facilitating collaboration across traditional organisational boundaries, driving the rapid development of skills and capabilities to meet changing business conditions, and evaluating employee performance and providing appropriate feedback. Deloitte ${ }^{31}$ proposes the DevelopDeploy-Connect Model, that is, focusing on critical workforce segments, developing and growing talent, and integrating human capital programmes to create a cohesive talent management strategy. The recommendation by Ashmead ${ }^{77}$ is country- specific in that: Asian countries - including China and India - increase investment in talent pipeline and talent worker acquisition, Brazil develop next generation of leaders, acquire new talent and ensure readiness of existing talent, and European countries create movement (rotation) for development without increasing the investment in the internal pipeline. Towers Watson ${ }^{78}$ recommends that the U.S. emphasise on ensuring readiness of criticalskill talent.

\footnotetext{
${ }^{75}$ Griffith Insurance Education Foundation (2011).

${ }^{76}$ Lesser et al. (2007).

77 Ashmead (2012).

${ }^{78}$ Towers Watson (2010).
} 
Convergence in financial services affects the availability of talent workers in the insurance labour market. As more products become hybrid and distributed via non-traditional channels, insurance specialists may find new opportunities in other financial services markets. Geographical expansion of insurance, banking and investment services - increasingly via financial services conglomeration-is also generating new business and, thus, employment opportunities in new territories. As such, the search for top-quality senior management, middle-managers and professionals continues to expand outside the insurance industry, the local market, if not both. ${ }^{31}$ These phenomena of labour forces in transition across financial services industries and countries signal that insurance companies need well-articulated talent attraction and retention plans. The local academic institution and industry organisations should also play a role in producing new employees as well as training and retaining incumbent ones, respectively.

Again, the disparity in academic programmes and industry human-capital skills needs can inflate human capital obsolescence risk. The disparity may be soft skills-specific (e.g. oral and written presentation), knowledge-specific (e.g. the breadth of courses in the academic major) or both. The narrower the disparity, the lower the obsolescence risk management cost. All parties of interest are thus recommended to coordinate their efforts to find and retain workers-young and older-who are talented and possess the qualifications the industry needs.

\section{Acknowledgements}

The author thanks the 2013 Shin Awards Review Committee members for their anonymous but insightful comments.

\section{References}

Anderson, K. (1988) 'Why Johnny can't lead', Insurance Review 49(8): 22-27.

Ashmead, G. (2012) 'Public and private partnerships: Managing change in a fast moving world', WAPES World Congress, 27 June, Seoul, Korea.

Asian Development Bank (2012) Key Indicators for Asia and the Pacific: 2012 Edition, Manila: ADB.

Athley, R. (2004) It's 2008: Do you know where your talent is? A Deloitte Research Paper, New York: Deloitte Development, LLP.

Banister, J., Bloom, D. and Rosenberg, L. (2010) Population aging and economic growth in China, Program on the Global Demography of Aging Working Paper 53, Harvard University.

Bontis, N. and Serenko, A. (2009) 'A causal model of human capital antecedents and consequents in the financial services industry', Journal of Intellectual Capital 10(1): 53-69.

Brown, J., Kapteyn, A., Luttmer, E. and Mitchell, O. (2011) Do consumers know how to value annuities? Complexity as a barrier to annuitization, Working Paper WR-924-SSA, Financial Literacy Center of the Rand Corporation, Washington, DC.

Business Insurance (2012) 'Recruiting new risk management talent', (reprint from 15 October).

Cappelli, P. (ed.) (2008) 'The return on talent management investments: How to maximize the value of internal development', in Talent on Demand: Managing Talent in an Age of Uncertainty, Boston: Harvard Business Press.

Cole, C. and McCullough, K. (2012) 'The insurance industry's talent gap and where we go from here', Risk Management and Insurance Review 15(Spring): 107-116.

Dean, D. and Cianni, M. (2011) 'The manager's role in M\&A', Emphasis 23(January): 12-15. 
De Grip, A. (2004) 'Evaluating human capital obsolescence', EC-OECD Seminar on Human Capital and Labor Market Performance, 8 December, Brussels.

Deloitte (2006) How Can Insurance Companies Beat the Talent Crisis, New York: Deloitte.

Deloitte (2007) Generation Talent Management for Insurers, New York: Deloitte.

Deloitte (2010) Talent Edge 2020: Blueprints for the New Normal, New York: Deloitte.

Dorfman, M. (1990) 'Insurance in the undergraduate curriculum', Journal of Risk and Insurance 57(1): 45-65.

Employee Benefits Research Institute (EBRI) and Matthew Greenwald \& Associates (2012) 2012 Retirement Confidence Survey, March.

European Council (2000) [Lisbon European Council] Presidency Conclusions, 23-24 March, Lisbon [consilium.europa.eu/].

European Council (2010) Euro 2020: A European Strategy for Smart, Sustainable and Inclusive Growth, 3 March, Brussels.

Eurostat (2004) HRI Fortnight Report, 12 May.

Gardner, L. and Schmit, J. (1995) 'Collegiate risk management and insurance programs', Journal of Risk and Insurance 62(4): 625-648.

Griffith Insurance Education Foundation (2011) Report on Existing Millennial Research, 21 November, Worthington: The Griffith Insurance Education Foundation.

Gustavson, S. (1991) 'Crisis on the campus', Best's Review (Property and Casualty Edition) 91(January): 29-32.

Harter, J., Schmidt, F., Killham, E. and Asplund, J. (1998) $Q^{12}$ Meta Analysis, Washington, DC: Gallup.

Harter, J., Schmidt, F., Killham, E. and Agrawal, S. (2009) $Q^{12}$ Meta Analysis: The Relationship Between Engagement at Work and Organizational Outcomes, Washington, DC: Gallup.

Insurance Information Institute (2012) Insurance Industry Employment Trend: 1990-2012, December, New York: Insurance Information Institute.

Jacobson (2010 and 2012) Insurance Labor Market Survey, 10 February 2010; 7 August 2012, Chicago: Jacobson.

Japan Insurance Academy (1999) A Report of University Insurance-related Education Survey, Tokyo: Japan Insurance Culture Research Center, [in Japanese].

Jung, C. (2012) An Analysis of Mismatch in Human Resources Supply and Forecast, Seoul: KEIS, [in Korean].

Kahneman, D. and Tversky, A. (1979) 'Prospect theory: An analysis of decisions under risk', Econometrica 47(2): 263-272.

Kahneman, D. and Tversky, A. (1981) 'The framing of decisions and the psychology of choice', Science 211(January 30): 453-458.

Kim, H. (2010) 'RMI education in Asia', World Risk and Insurance Economics Congress, 25-29 July, Singapore.

Kim, H. (2012) A Study of Changes in Job Competency Requirement, Seoul: Employment Information Service (KEIS), [in Korean].

Korea Employment Information Service (KEIS) (2008) College Students' Job Preference Survey, Seoul: KEIS, [in Korean].

Korea Employment Information Service (KEIS) (2012) Labor Force Survey by Business and Occupation: The First Half of 2012, Seoul: KEIS, [in Korean].

Korea Research Institute for Vocational Education \& Training (KRIVET) (2012) Human Resources Development Indicators in Korea 2011, Seoul: KRIVET.

Kwon, W.J. (1999) Collegiate Insurance and Actuarial Science Education Asia, The Asia-Pacific Risk and Insurance Association Annual Conference, 18-21 July, Hong Kong.

Kwon, W., Park, M., Lee, S., Kim, J., Jun, J. and Park, S. (2012) Medium to Long-term Manpower Supply Forecast: 2011-2020, Seoul: Ministry of Employment and Labor and KEIS [in Korean].

Lee, M. (2008) Occupational Importance and Job Skill Requirements in the Insurance Market, e-Employment Issue, Seoul: Employment Information Service (KEIS). [in Korean].

Lesser, E., Ringo, T. and Blumberg, A. (2007) Transforming the Workforce: Seven Keys to Succeeding in a Globally Integrated World, Armonk, NY: IBM Institute for Business Value.

Lloyd's (2011) Lloyd's Risk Index 2011, London: Lloyd's.

Mandell, L. (2008) The Financial Literacy of Young American Adults: Results from the 2008 Jump\$tart Coalition Survey of High School Seniors and College Students, Washington, DC: The Jump\$tart Coalition. 
McKinsey \& Company (2010) Building a Talent Magnet: How the Property Casualty Industry Can Solve Its People Needs, New York: McKinsey \& Company.

Office of Personnel Management (OPM) (2008) An Analysis of Federal Employee Retirement Data: Predicting Future Retirements and Examining Factors Relevant to Retiring from the Federal Service, March, Washington, DC: Government Printing Office.

Organisation for Economic Co-operation and Development (OECD) (2009) 'Who participate in education?', in Education at a Glance, Paris: OECD Publishing.

Organisation for Economic Co-operation and Development (OECD) (2011) 'Who participate in education?', in Education at a Glance, Paris: OECD Publishing.

Organisation for Economic Co-operation and Development (OECD) (2012) 'Who participate in education?', in Education at a Glance, Paris: OECD Publishing.

Organisation for Economic Co-operation and Development (OECD) (2012) 'OECD StatExtracts-Labor Market Statistics', [online database].

Reputation Institute (2012a) Global RepTrak 100, Reputation Institute, http://www.reputationinstitute.com/ thought-leadership/global-reptrak-100.

Reputation Institute (2012b) Forbes/Reputation Institute US RepTrak Pulse Study, Reputation Institute. http://www.reputationinstitute.com/thought-leadership/global-reptrak-100

Seike, A., Biggs, S. and Sargent, L. (2012) Organizational, adaptation and human resource needs for an aging population, a chapter in John Beard et al. (eds.) Global Population Aging: Peril or Promise? Program on the Global Demography of Aging Working Paper 89, Harvard University.

Stewart, S. (2009) 'Talent Management and Succession Planning in the European Insurance Industry', 8 July, http://www.content.spencerstuart.com/sswebsite/pdf/lib/InsuranceTM.pdf.

Strange, T. and Barley, A. (2008) OECD Insights: Sustainable Development: Linking Economy, Society, Environment, Paris: OECD Publishing.

Sun Life Financial (2011) 'Sun Life Unretirement Index', October.

Sweet, S., Pitt-Catsouphes, M., Besen, E., Hovhannisyan, S. and Pasha, F. (2010) Talent Pressures and the Aging Workforce: Responsive Action Steps for the Finance and Insurance Sector, Insurance Sector Report 7.1, August, Boston: The Sloan Center on Aging and Population.

Towers Watson (2010) Creating a Sustainable Rewards and Talent Management Model: Global Talent Management and Rewards Survey Report, New York: Towers Watson.

Towers Watson (2011) The Talent Management and Rewards Imperative for 2012: Learning Through Uncertain Times, New York: Towers Watson.

Towers Watson (2012) 2012 Global Workplace Survey at a Glance, New York: Towers Watson.

U.S. Bureau of Labor Statistics Database (2012) http://www.bls.gov/data/, accessed in December 2012.

U.S. Department of Education (2000) Before It's too Late: A Report to the National Commission on Mathematics and Science Teaching for the 21st Century, 27 September, Jessup: U.S. Department of Education.

U.S. Government Accountability Office (GAO) (2012) Human Capital Management: Effectively Implementing Reforms and Closing Skills Gaps Are Key to Address Federal Workforce Challenges (GAO-12-1023T), Washington, DC: U.S. Government Printing Office.

Welch, D. (2004) 'Mutual Omaha's Healthy Preoccupation with Talent', Gallup Managerial Journal, 13 May [online] http://businessjournal.gallup.com

Yaari, M. (1965) 'Uncertain lifetime, life insurance and the theory of the consumer', Review of Economic Studies 32(April): 137-150.

Zurich American Life Insurance Company (2012) Maximizing the Value of Employee Benefits, Kansas: Zurich American Life Insurance Company.

\section{About the Author}

W. Jean Kwon holds the Manton/AIG Endowed Chair Professorship in International Insurance and Risk Management at the School of Risk Management of St. John's University in New York City. He co-founded the Asia-Pacific Risk and Insurance 
Association, organised the first two World Risk and Insurance Economics Congresses, has written several books including Kulp-Wright award-winning Risk Management and Insurance Perspectives in a Global Economy, and offers services to public and private sector organisations internationally. He specialises in insurance market and country analysis, strategic, financial and operational performance analysis, and insurance laws and regulation. 